\title{
Pengaruh Sistem Aerasi Intermittent terhadap Removal Organik dan Nitrogen pada Pengolahan Air Limbah Domestik Kamar Mandi Umum
}

\author{
Afifah Munfaridah1*, Sri Puji Saraswati1,2, Johan Syafri Mahathir ${ }^{2}$
}

1Magister Teknik Sistem, Universitas Gadjah Mada, Jalan Teknika Utara No.3 Kabupaten Sleman, Yogyakarta 55281 Indonesia; 2Departemen Teknik Sipil dan Lingkungan, Universitas Gadjah Mada Jalan Grafika Kampus No.2 Kabupaten Sleman, Yogyakarta 55284 Indonesia

\begin{abstract}
ABSTRAK
Sebuah instalasi pengolahan air limbah (IPAL) dibangun untuk mengolah air limbah greywater dan blackwater dari toilet dan kamar mandi umum Wisdom Park UGM yang terletak di Dusun Kuningan, Catur Tunggal, Sleman, Daerah Istimewa Yogyakarta. Unit reaktor proses IPAL tersebut terdiri dari sedimentasi, ekualisasi, aerasi 1, aerasi 2 dan secondary clarifier dengan sistem pengolahan berupa aerasi intermitten dan aerasi kontinyu dengan menggunakan Microbubble Generator (MBG) dan blower. Saat ini belum pernah dilakukan kajian terkait efektivitas sistem proses biologi pada IPAL dalam menurunkan kandungan organik dan nitrogen air limbah. Suatu sistem aerasi intermitten diaplikasikan dengan tujuan untuk mendegradasi kandungan organik dan nitrogen yang terkandung dalam air limbah, juga dapat meningkatkan dan meratakan suplai oksigen sehingga kemampuan penyerapan oksigen menjadi lebih besar. Evaluasi IPAL dilakukan selama 82 hari pengamatan dengan parameter air limbah yang diujikan terdiri dari $\mathrm{COD}_{2} \mathrm{NH}_{3}-\mathrm{N}, \mathrm{NO}_{3}-$ $\mathrm{N}, \mathrm{NO}_{2}-\mathrm{N}$, dan $\mathrm{PO}_{4}-\mathrm{P}$ yang nantinya akan dibandingkan dengan PerMenLHK No 68 Tahun 2016 tentang Baku Mutu Air Limbah Domestik. Hasil performa removal kontaminan di tangki aerasi 1 dan tangki aerasi 2 tidak jauh berbeda, sehingga menunjukkan

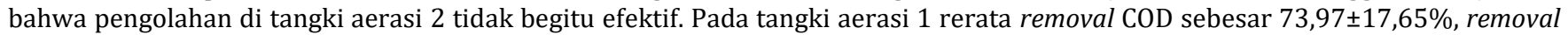

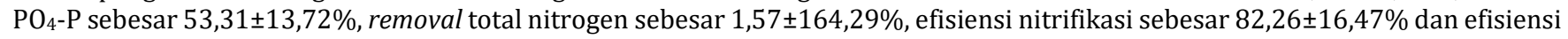
denitrifikasi sebesar $-66,4 \pm 373,37 \%$. Sedangkan, total konsumsi energi yang dibutuhkan untuk pengolahan air limbah di IPAL dengan debit rerata 82,06 l/hari sebesar 43,13 kWh/m³ dan biaya sebesar Rp 62.326,00/m³. Dengan konsumsi energi terbesar dihasilkan untuk peyisihan fosfat yaitu 2,99 $\mathrm{kWh} / \mathrm{gPO}_{4}-\mathrm{P}$, penyisihan total nitrogen sebesar 1,33 kWh/gTN, penyisihan ammonia sebesar 0,88 $\mathrm{kWh} / \mathrm{gNH}_{3}-\mathrm{N}$, dan penyisihan COD sebesar 0,7 kWh/gCOD.
\end{abstract}

Kata Kunci: aerasi intermittent, microbubble generator, nitrifikasi - denitrifikasi, total removal, konsumsi energi

\begin{abstract}
A wastewater treatment plant (WWTP) was built to treat greywater and blackwater from the public toilets and bathrooms of Wisdom Park UGM located in Dusun Kuningan, Catur Tunggal, Sleman, Special Region of Yogyakarta. The WWTP process reactor unit consists of sedimentation, equalization, aeration 1, aeration 2 and secondary clarifier with a processing system in the form of intermittent aeration and continuous aeration using a Microbubble Generator (MBG) and a blower. Currently, no study has been conducted regarding the effectiveness of the biological process system in WWTPs in reducing the organic and nitrogen content of wastewater. An intermittent aeration system is applied with the aim of degrading organic and nitrogen content contained in wastewater, as well as increasing and leveling oxygen supply so that oxygen absorption capacity becomes greater. The WWTP evaluation was carried out for 82 days of observation with the tested wastewater parameters consisting of $\mathrm{COD}, \mathrm{NH}_{3}-\mathrm{N}, \mathrm{NO}_{3}-\mathrm{N}, \mathrm{NO}_{2}-\mathrm{N}$, and $\mathrm{PO}_{4}-\mathrm{P}$ which will later be compared with the Minister of Environment and Forestry's Regulation No. 68, 2016 on Domestic Wastewater Quality Standards. The results of the contaminant removal performance in aeration tank 1 and aeration tank 2 were not much different, indicating that the treatment in aeration tank 2 was not very effective. In aeration tank 1 the mean COD removal was $73,97 \pm 17,65 \%$, $\mathrm{PO}_{4}$-P removal was $53,31 \pm 13,72 \%$, total nitrogen removal was $1,57 \pm 164,29 \%$, nitrification efficiency was $82,26 \pm 16,47 \%$, and denitrification efficiency was $-66,4 \pm 373,37 \%$ in aeration tank 1 . Meanwhile, the total energy consumption required for wastewater treatment at WWTP with an average discharge $82.06 \mathrm{l} /$ day is $43.13 \mathrm{kWh} / \mathrm{m}^{3}$ and a cost of Rp. $62,326.00 / \mathrm{m}^{3}$. Phosphate removal required the most energy, at $2.99 \mathrm{kWh} / \mathrm{gPO}_{4}-\mathrm{P}$, followed by total nitrogen removal at $1.33 \mathrm{kWh} / \mathrm{gTN}$, ammonia removal at 0.88 $\mathrm{kWh} / \mathrm{gNH}_{3}-\mathrm{N}$, and COD removal at $0.7 \mathrm{kWh} / \mathrm{gCOD}$.
\end{abstract}

Keywords: intermittent aeration, micobubble generator, nitrification - denitrification, removal, energy consumption

Sitasi: Munfaridah, A., Saraswati, S.P., Mahathir, J.S. (2022). Pengaruh Sistem Aerasi Intermittent terhadap Removal Organik dan Nitrogen pada Pengolahan Air Limbah Domestik Kamar Mandi Umum. Jurnal Ilmu Lingkungan, 20(1),102-114, doi: 10.14710/jil.20.1.102-114

* Penulis korespondensi: afifahmunfaridah@mail.ugm.ac.id 


\section{Pendahuluan}

Pengelolaan air limbah domestik saat ini menjadi isu penting yang muncul di Indonesia, sejalan dengan meningkatnya pertumbuhan penduduk dan perkembangan pembangunan yang semakin pesat. Menurut DLHK Provinsi DIY, sebanyak 10 sungai di Yogyakarta hampir seluruhnya tercemar dalam kategori rendah dan sedang akibat pembuangan air limbah rumah tangga langsung ke sungai. Hasil indeks kualitas air Provinsi DIY tahun 2019 masuk kedalam kategori "sangat kurang baik" dalam skala nasional dengan nilai 35,37 (Kementerian Lingkungan Hidup dan Kehutanan, 2019).

Kali Belik merupakan salah satu sub aliran sungai yang berada di tengah Kota Yogyakarta, dimana salah satu sumber air limbah yang dibuang berasal dari limbah toilet umum Wisdom Park. Wisdom Park merupakan ruang terbuka hijau milik UGM yang digunakan untuk kegiatan penelitian, olahraga, rekreasi maupun pelestarian kearifan lokal. Air Limbah yang berasal dari toilet umum Wisdom Park UGM dikelola di IPAL Kuningan sebelum dibuang ke Kali Belik. IPAL Kuningan mengolah limbah black water yang berasal dari kakus dan limbah grey water yang berasal dari floor drain.

Pemerintah Provinsi DI Yogyakarta dalam mengatasi permasalahan air limbah domestik mengeluarkan Peraturan Daerah Daerah Istimewa Yogyakarta Nomor 7 Tahun 2016 tentang Baku Mutu Air Limbah. Bangunan rumah tinggal dan non rumah tinggal wajib mengelola limbah cair domestik berupa greywater dan blackwater sebelum dibuang ke saluran umum atau badan air. Karakteristik grey water sangat bervariasi, tergantung kegiatan yang dilakukan. Air limbah yang berasal dari kegiatan mandi dan mencuci akan banyak menghasilkan Chemical Oxygen Demand (COD) dan fosfat hasil dari penggunaan sabun dan deterjen (Ajit, 2016). Sedangkan black water berasal dari toilet, urinoir dan kakus yang mengandung mikroba patogen dan urin yang umumnya mengandung nitrogen dan fosfat (Tendean, Tilaar and Karongkong 2014). Diharapkan dengan adanya pengolahan di IPAL Kuningan, parameter tersebut dapat sesuai dengan baku mutu Permen LHK nomor 68 Tahun 2016. Beberapa faktor yang menjadi penyebab parameter air limbah masih melampaui baku mutu yang ditetapkan antara lain waktu tinggal hidrolik yang terlalu singkat, fluktuasi debit limbah terlalu besar, fungsi aerasi kurang baik, dan kesalahan operasional oleh operator (Said \& Utomo, 2018).

Kandungan COD, nitrogen dan fosfat dalam pengolahan air limbah organik secara biologi masih dibutuhkan keberadaanya. Namun, apabila kandungan nitrogen dan fosfat berlebihan akan menyebabkan pencemaran lingkungan serta berdampak buruk pada keseimbangan ekologi dan kesehatan manusia. Pemilihan teknologi hendaknya lebih ekonomis, hemat energi, operasional dan pemeliharaan mudah, efektif dan stabil agar dapat diaplikasikan dan diterima secara sosial. Salah satu teknologi yang merupakan solusi sederhana dan ekonomis yaitu pe.ngolahan biologis dengan sistem aerasi (Ayu et al., 2002).

Berdasarkan uraian permasalahan tersebut, maka perlu dilakukan penelitian di IPAL Wisdom Park Kuningan yang sebelumnya belum pernah diketahui efektivitas kinerjanya. Sistem pengolahan yang digunakan berupa aerasi intermittent dan aerasi kontinyu dengan menggunakan Microbubble Generator (MBG) dan blower. Sistem aerasi intermittent bertujuan untuk menghasilkan proses aerobik - anoksik sekaligus dalam satu tangki, sehingga lebih ekonomis dan praktis. Sedangkan, proses aerasi kontinyu menggunakan blower selama 24 jam yang bertujuan untuk mendegrasi air limbah yang tersisa. Selain itu, ditambahkan proses resirkulasi efluen dari tangki secondary clarifier ke tangki aerasi 1 . Cara demikian diharapkan selain meningkatkan jumlah mikroorganisme untuk mendegradasi air limbah, juga meningkatkan dan meratakan suplai oksigen sehingga kemampuan penyerapan oksigen menjadi lebih besar (Ávila et al., 2017). Pengolahan air limbah dengan sistem aerasi intermittent juga diharapkan mampu mengurangi penggunaan energi listrik sehingga dapat mengurangi biaya operasional IPAL. Tujuan dari penelirian ini penelitian untuk mengetahui kinerja dan konsumsi energi yang dibutuhkan IPAL Wisdom Park Kuningan yang sebelumnya belum pernah diketahui efektivitas kinerja dalam pengolahan air limbah dalam menurunkan kandungan COD, nitrogen dan fosfat.. Manfaat yang didapatkan dari penelitian ini diantaranya dapat memberikan informasi kepada masyarakat terkait efektivitas pengolahan dan kehandalan IPAL dalam menyisihkan kontaminan dalam air limbah, serta total konsumsi energi dan biaya operasional yang dibutuhkan pada pengolahan air limbah dengan sistem aerasi intermittent.

\section{Metodologi}

\subsection{Proses Pengolahan IPAL}

Lokasi IPAL Kuningan terletak di area area bagian belakang Wisdom Park atau sebalah utara Gedung Pusat Studi Lingkungan Hidup (PSLH) UGM. IPAL Kuningan mengolah limbah black water dan grey water dari toilet umum di Wisdom Park. Diagram alir pengolahan IPAL Kuningan disajikan pada Gambar 1. 


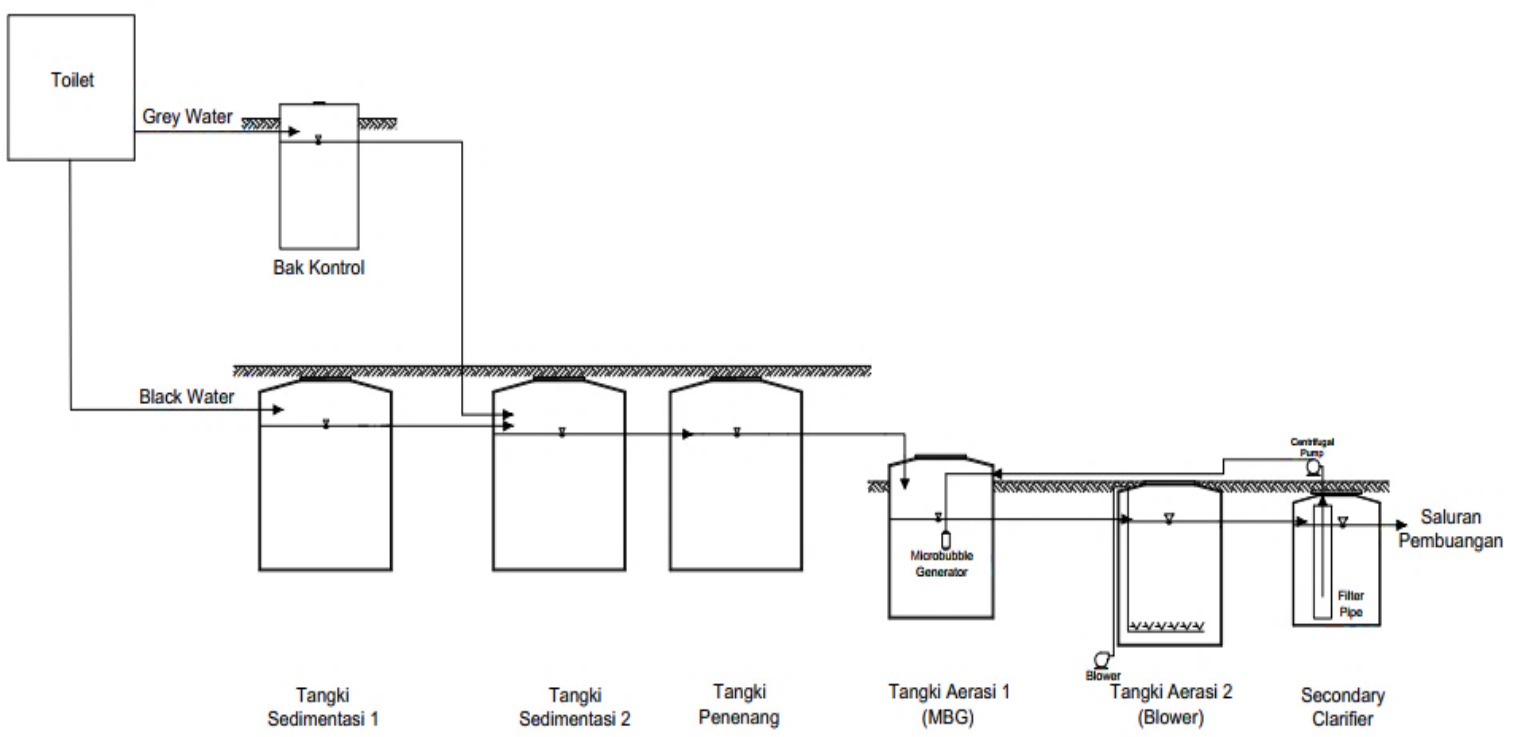

Gambar 1 Diagram Alir IPAL Kuningan

Air limbah black water masuk ke tangki sedimentasi 1, sedangkan limbah grey water masuk ke tangki sedimentasi 2 kemudian masuk ke tangki sedimentasi 3 untuk menghomogenkan aliran. Objek penelitian yang dimulai dari outlet tangki sedimentasi 3 sebagai influen sampai outlet tangki secondary clarifier sebagai efluen. Pengolahan di tangki aerasi 1 menggunakan sistem aerasi intermittent dengan microbubble generator (MBG), dimana lama siklus aerasi intermittent yaitu 15 menit on dan 15 menit off. Sedangkan proses di tangki aerasi 2 dengan sistem aerasi kontinyu menggunakan blower. Selain itu, terjadi proses resirkulasi efluen dari tangki secondary clarifier menuju ke tangki aerasi 1 dengan debit resirkulasi sebesar 650 liter/jam.

\subsection{Metode Sampling}

Pengambilan sampel air limbah dilakukan setiap Hari Selasa dan Jumat mulai tanggal 13 Oktober 2020 1 Januari 2021 pukul 07.00 WIB. Standar prosedur pengambilan dan penyimpanan sampel uji kualitas air limbah yang digunakan adalah standar EPA dan SNI 6989.57:2008. Pengukuran parameter yang dilakukan secara langsung atau on site diantaranya debit, oksigen terlarut (DO) dan konsumsi energi. Pengukuran debit IPAL dilakukan pada pipa outlet dengan menampung air limbah menggunakan ember berukuran 50 liter selama kurang lebih 10 jam mulai pukul $07.00 \mathrm{~s} / \mathrm{d}$ 17.00. Sedangkan pengukuran parameter DO dilakukan pada masing-masing tangki dengan menggunakan Dissolved Oxygen Meter dan pengukuran konsumsi energi untuk pompa MBG dan blower menggunakan kWh meter.

\subsection{Analisis Data}

Peraturan yang digunakan sebagai pembanding standar baku mutu efluen dalam penelitian ini adalah Peraturan Menteri Lingkungan Hidup dan Kehutanan Nomor 68 Tahun 2016 tentang Baku Mutu air Limbah Domestik. Parameter kualitas air limbah yang diujikan di laboratorium diantaranya $\mathrm{COD}, \mathrm{NH}_{3}-\mathrm{N}, \mathrm{NO}_{3}-\mathrm{N}, \mathrm{NO}_{3}-$ $\mathrm{N}, \mathrm{PO}_{4}-\mathrm{P}$ dan TSS dengan metode yang disajikan pada Tabel 2.

Analisis performa masing - masing tangki seperti efisiensi removal, efisiensi nitrifikasi - denitrifikasi, total nitrogen removal dan konsumsi energi dihitung menggunakan rumus yang disajikan pada Tabel 2 .

\section{Hasil dan Pembahasan}

\subsection{Analisis Debit IPAL}

Debit outlet di IPAL Kuningan diasumsikan sama dengan debit inlet, hal ini dikarenakan sistem yang digunakan adalah tertutup sehingga dianggap tidak terjadi penguapan. Meskipun pada kondisi aktual, debit yang masuk pada masing-masing tangki akan berbeda. 
Debit air limbah yang masuk ke tangki aerasi 1 akan lebih stabil dibandingkan debit inlet yang masuk ke tangki sedimentasi 1 dan sedimentasi 2 . Hal ini dikarenakan adanya tangki sedimentasi 3 yang juga berfungsi sebagai tangki ekualisasi, yaitu untuk menghomogenkan aliran yang masuk. Profil Debit harian IPAL Kuningan disajikan pada Gambar 2.

Debit air limbah yang masuk ke IPAL Kuningan tergolong stabil dan tidak terlalu berbeda antara Hari
Selasa dan Jum'at. Hal ini dikarenakan saat ini jumlah pengguna setiap harinya kurang lebih sama dan belum ada kegiatan lain di Wisdom Park sehingga belum banyak pengunjung yang datang. Rata-rata debit di IPAL Kuningan sebesar $0,082 \mathrm{~m}^{3} /$ hari dengan debit maksimum $0,123 \mathrm{~m}^{3} /$ hari pada hari ke-36 dan debit minimum $0,038 \mathrm{~m}^{3} /$ hari pada hari ke-14.

Tabel 1 Metode Analisis Laboratorium

\begin{tabular}{clll}
\hline $\mathbf{N o}$ & \multicolumn{1}{c}{ Parameter } & \multicolumn{1}{c}{ Reagen } & \multicolumn{1}{c}{ Metode Uji } \\
\hline $\mathbf{1}$ & Chemical Oxygen Demand & Larutan baku: Kalium Dikromat 0,1 N & Titrimetri APHA Q998 \\
$\mathbf{2}$ & Amonia $\left(\mathrm{NH}_{3}-\mathrm{N}\right)$ & Amonia ISA (HACH, Germany Cat.4447169-ID) & $\begin{array}{l}\text { Amonia Combination ISE NH } 3 \text { 181- } \\
\text { HACH }\end{array}$ \\
$\mathbf{3}$ & Fosfat $\left(\mathrm{PO}_{4}-\mathrm{P}\right)$ & Molybdvanadate (HACH, Germany Cat. 2076032-ID) & Spektofotometri APHA 1998 \\
& & NitriVer 3 reagent powder pillows (HACH, Germany & Spektofotometri APHA 1998 \\
$\mathbf{4}$ & Nitrit $\left(\mathrm{NO}_{2}-\mathrm{N}\right)$ & Cat. 2107169-ID) & \\
& & NitraVer 5 Nitrate (HACH, Germany) Cat. 2106169- & Spektofotometri APHA 1998 \\
$\mathbf{5}$ & Nitrat $\left(\mathrm{NO}_{3}-\mathrm{N}\right)$ & ID & Gravimetri APHA 1998 \\
$\mathbf{6}$ & Total Suspended Solid (TSS) & & -
\end{tabular}

Tabel 2 Analisis Perhitungan

\begin{tabular}{|c|c|}
\hline Persamaan & \\
\hline$E=1-\frac{\mathrm{C}_{\mathrm{ef}}}{\mathrm{C}_{\mathrm{in}}} \times 100 \%$ & $\begin{array}{l}\mathrm{E}=\text { Efisiensi Removal }(\%) \\
\mathrm{C}_{\text {in }}=\text { konsentrasi pada influen }(\mathrm{mg} / \mathrm{l}) \\
\mathrm{C}_{\mathrm{ef}}=\text { konsentrasi pada efluen }(\mathrm{mg} / \mathrm{l})\end{array}$ \\
\hline $\begin{array}{l}\text { E Nitrifikasi }=1-\frac{\mathrm{NH}_{3} \mathrm{~N}_{\text {out }}}{\mathrm{NH}_{3} \mathrm{~N}_{\text {in }}} x 100 \% \\
\text { E Denitrifikasi }=1-\frac{\left(\mathrm{NO}_{2} \mathrm{~N} \text { out }+\mathrm{NO}_{3} \mathrm{~N} \text { out }\right)}{\left(\mathrm{NH}_{3} \mathrm{~N} \text { in }-\mathrm{NH}_{3} \mathrm{~N} \text { out }\right)} \\
\text { Total Nitrogen Removal } \\
=1-\frac{\left(\mathrm{NH}_{3} \mathrm{~N} \text { out }+\mathrm{NO}_{2} \mathrm{~N} \text { out }+\mathrm{NO}_{3} \mathrm{~N} \text { out }\right)}{\left(\mathrm{NH}_{3} \mathrm{~N} \text { in }+\mathrm{NO}_{2} \mathrm{~N} \text { in }+\mathrm{NO}_{3} \mathrm{~N} \text { in }\right)}\end{array}$ & $\begin{array}{l}\mathrm{NH}_{3}-\mathrm{N} \text { in }=\text { Konsentrasi amonia influen } \\
\mathrm{NH}_{3}-\mathrm{N} \text { out = Konsentrasi amonia efluen } \\
\mathrm{NO} 2-\mathrm{N} \text { in = Konsentrasi nitrit influen } \\
\text { NO2-N out = Konsentrasi nitrit influen } \\
\text { NO3-N in = Konsentrasi nitrat influen } \\
\text { NO3-N out = Konsentrasi nitrat influen }\end{array}$ \\
\hline $\begin{array}{l}k W h / m 3=\frac{\text { total penggunaan energi }}{\text { total Debit }} \\
\frac{k W h}{\text { gremoved }}=\frac{\text { total penggunaan energi }}{\text { rerata Removal }}\end{array}$ & $\begin{array}{l}\text { Rerata removal = rata-rata penyisihan polutan } \\
\mathrm{PO}_{4}-\mathrm{P}, \mathrm{NH}_{3}-\mathrm{N}, \mathrm{TN} \text { dan } \mathrm{COD}(\mathrm{g})\end{array}$ \\
\hline
\end{tabular}




\subsection{Konsentrasi Efluen}

Hasil analisis konsentrasi efluen di IPAL Kuningan menggunakan sistem aerasi menunjukkan adanya penurunan konsentrasi dari influen ke effluen, meskipun terdapat beberapa parameter yang masih berada diatas baku mutu yang ditetapkan. Rerata konsentrasi COD sudah memenuhi baku mutu, sedangkan parameter $\mathrm{PO}_{4}-\mathrm{P}$ dan $\mathrm{NH}_{3}-\mathrm{N}$ masih berada diatas baku mutu. Baku mutu parameter $\mathrm{NO}_{3}-\mathrm{N}$ dan $\mathrm{NO}_{2}-\mathrm{N}$ untuk kriteria IPAL Domestik tidak ditentukan dalam Permen LHK No 68/2016 dan PerdaDIY No.7/2016. Apabila dibandingkan dengan baku mutu kategori kegiatan industri lainnya pada PerdaDIY No.7/2016, parameter $\mathrm{NO}_{3}-\mathrm{N}$ sudah memenuhi yaitu dibawah $20 \mathrm{mg} / \mathrm{l}$, sedangkan $\mathrm{NO}_{2}-\mathrm{N}$ belum memenuhi baku mutu yaitu masih diatas $1 \mathrm{mg} / \mathrm{l}$. Meskipun demikian pengolahan dengan sistem aerasi intermittent dinilai baik untuk menurunkan kandungan kontaminan dalam air limbah grey water dan black water.

Rasio rata - rata efluen C:N:P pada tangki aerasi 1 sebesar 7,1 : 2,5 : 1 dan pada tangki aerasi 2 yang didapatkan sebesar $4: 3,9: 1$. Menurut (Metcalf \& Eddy, 2003), rasio C:N:P untuk pengolahan aerob yaitu 100:5:1. Kondisi di IPAL Kuningan menunjukkan bahwa terjadi ketidak seimbangan antara rasio $\mathrm{C}: \mathrm{N}: \mathrm{P}$. Rasio $\mathrm{C}$ dan $\mathrm{N}$ yang tidak seimbang dapat menyebabkan proses defisiensi nutrien dalam sistem, maka perlu penambahan $\mathrm{C}$ dan $\mathrm{N}$ secara berkala. Konsentrasi nitrogen yang terlalu tinggi akan menyebabakan rising sludge dan foam dimana akan terbentuk gumpalan lumpur yang terisi gelembung-gelembung nitrogen dan menyebabkan lumpur naik ke permukaan tangki (Hanafi, 2019). Resume efluen konsentrasi IPAL disajikan pada tabel 3.

Tabel 3 Konsentrasi Efluen IPAL

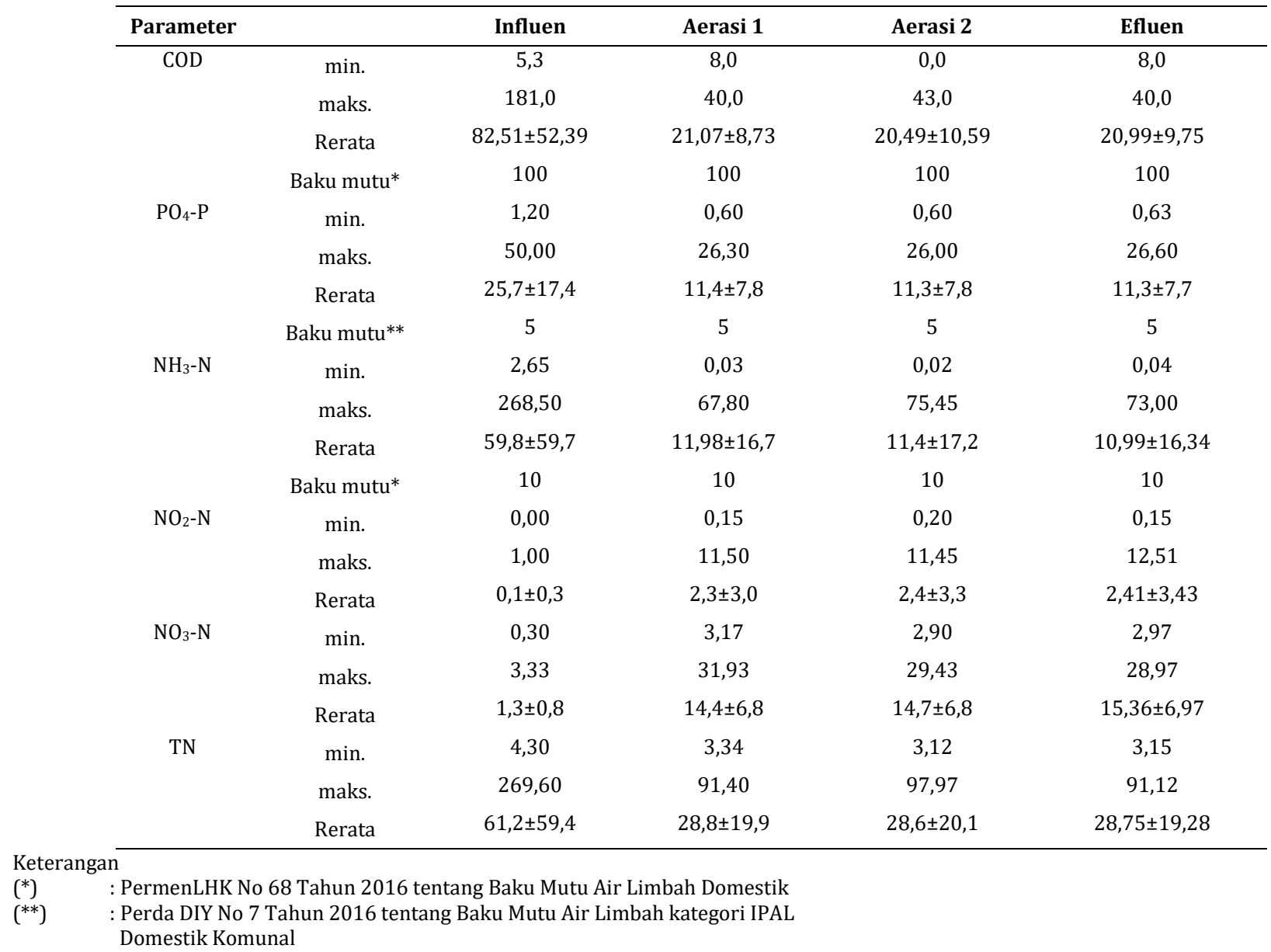




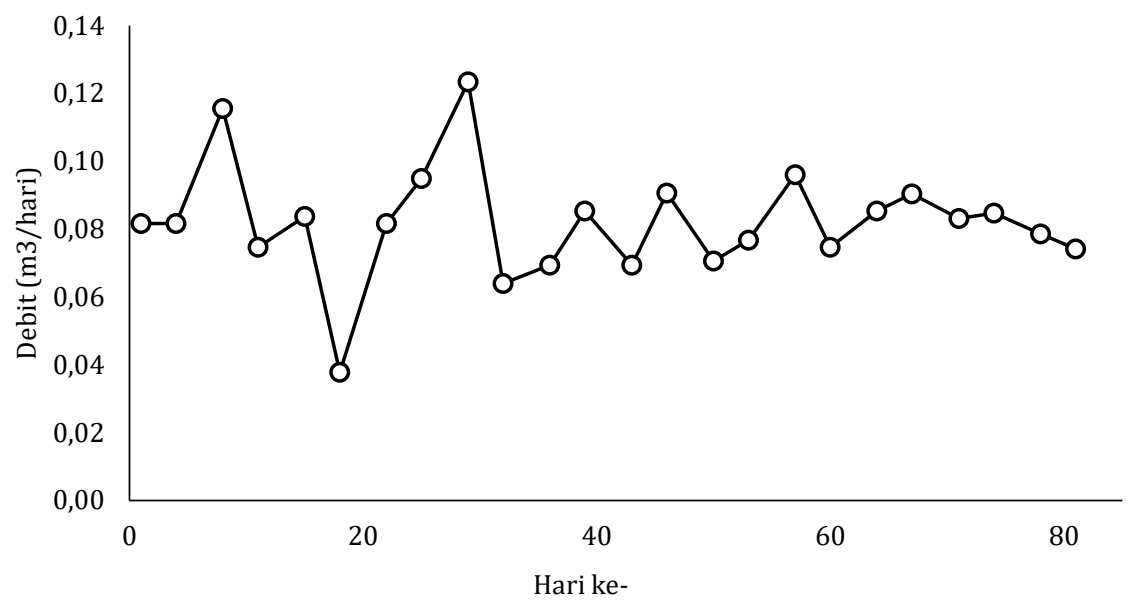

Gambar 2 Profil Debit IPAL Kuningan

\subsection{Performa Removal Efluen}

Analisis removal parameter yang dilakukan di IPAL Kuningan dianatara removal COD, fosfat (PO4-P), total nitrogen dan nitrifikasi-denitrifikasi. Pengambilan sampel dilakukan selama 81 hari dengan nilai organic loading rate (OLRv) desain sebesar 0,67 $\mathrm{kgCOD} / \mathrm{m}^{3} /$ hari dan OLRv aktual sebesar 0,07 $\mathrm{kgCOD} / \mathrm{m}^{3} /$ hari, sehingga didapatkan nilai OLRv aktual sebesar 1/9 dari OLRv desain. Nilai OLRv menunjukkan jumlah kandungan organik dalam air limbah yang diuraikan oleh mikroorganisme dalam tangki per unit volume per hari (von Sperling et al., 2020). Kondisi tersebut menunjukkan beban organik yang masuk ke IPAL Kuningan masih sedikit dan masih sesuai dengan desain. Resume performa removal dari masing-masing parameter IPAL disajikan pada tabel 4 .

Tabel 4 Performa Removal IPAL

\begin{tabular}{ccccc}
\hline Parameter & & Aerasi 1 & Aerasi 2 & $2^{\text {nd }}$ Clarifier \\
\hline COD removal, \% & min. & 0,00 & 61,54 & 7,69 \\
& maks. & 91,71 & 86,74 & 88,17 \\
& Rerata & $71,98 \pm 21,24 \%$ & $75,38 \pm 6,67 \%$ & $74,62 \pm 19,38 \%$ \\
PO4-P removal, \% & min. & 35,96 & 36,69 & 35,23 \\
& maks. & 73,73 & 73,16 & 73,31 \\
& Rerata & $56,67 \pm 10,91 \%$ & $57,04 \pm 10,68 \%$ & $56,88 \pm 10,52 \%$ \\
Efisiensi Nitrifikasi, \% & min. & 68,28 & 66,44 & 59,46 \\
& maks. & 99,58 & 99,73 & 99,76 \\
Efisiensi Denitrifikasi, \% & Rerata & $83,39 \pm 11,23 \%$ & $83,82 \pm 12,2 \%$ & $84,41 \pm 12,38 \%$ \\
& min. & 58,40 & 54,42 & 48,96 \\
& maks. & 88,24 & 88,97 & 90,73 \\
& Rerata & $74,38 \pm 9,94 \%$ & $73,63 \pm 10,89 \%$ & $72,42 \pm 12,15 \%$ \\
& min. & 41,97 & 37,06 & 29,92 \\
& maks. & 85,29 & 86,95 & 87,27 \\
\hline
\end{tabular}


Berdasarkan hasil analisis performa removal dapat dibuktikan bahwa IPAL Kuningan dengan sistem aerasi intermittent dapat efektif menyisihkan kontaminan dalam air limbah, meskipun rata - rata efisiensi denitrifikasi masih bernilai negatif. Nilai negatif ini menunjukkan bahwa terjadi peningkatan nitrat dalam air limbah. Selain itu, efisiensi pada tangki aerasi 1 dan tangki aerasi 2 tidak menunjukkan selisih nilai yang jauh berbeda. Hal ini menunjukkan bahwa performa pada tangki aerasi 2 dengan sistem aerasi kontinyu tidak terlalu berpengaruh dalam menyisihkan kontaminan karena sudah tersisihkan di tangki aerasi 1 dengan sistem aerasi intermittent.

Performa removal kontaminan dalam air limbah dipengaruhi oleh beberapa faktor, diantaranya performa volumetric loading rate, rasio $\mathrm{C} / \mathrm{N}$ dan rasio F/M. Volumetric loading rate (VLR) dalam air limbah merupakan salah satu faktor yang mempengaruhi performa removal konsentrasi. VLR akan mempengaruhi removal rate COD amonia nitrogen, dimana semakin besar VLRvmaka removal rate juga meningkat. VLR dari tangki aerasi 1 ke tangki aerasi 2 dan ke tangki secondary clarifier mengalami penurunan, sehingga dapat dikatakan bahwa tangki aerasi 1 memiliki peran paling besar untuk menyisihkan konsentrasi efluen. Peningkatan VLR akan meningkatkan pertumbuhan biomassa dan nantinya dapat menyebabkan peningkatan konsumsi organik. Gambar 3 menunjukkan grafik box plot organic loading rate dan ammonia laoding rate.

Penurunan organic loading rate dari masingmasing tangki juga terjadi pada penelitian yang

\section{Aerasi $1 \square$ Aerasi $2 \square$ 2nd Clarifier}

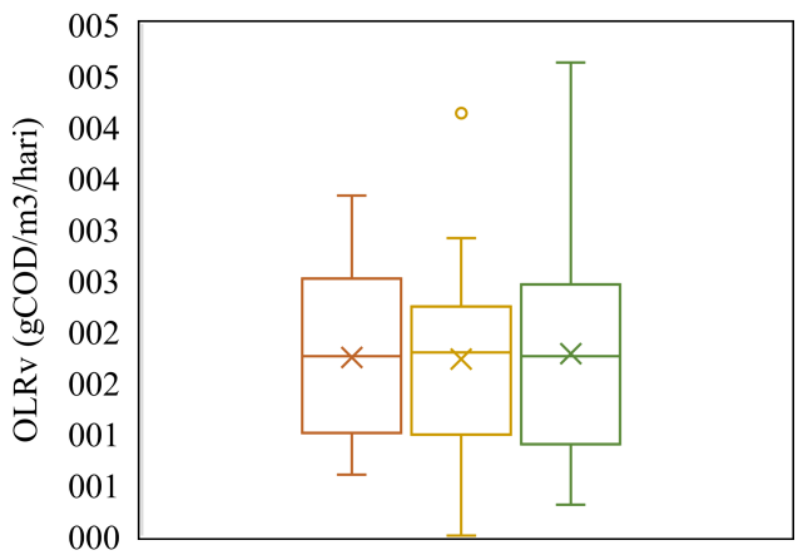

(a) dilakukan oleh (Torkaman et al., 2015), dengan menggunakan sistem pengolahan moving be biofilm reactors (MBBR). Apabila dilihat dari konfigurasi reaktor, proses pada tangki aerob dapat mengurangi pengaruh variasi organic loading rate terhadap organic removal rate. Selain itu, terjadi hubungan linier antara organic loading rate dan removal rate COD. Menurut (Najafpour et al., 2006), nilai organic loadinging rate akan meningkat diikuti dengan peningkatan organic removal rate. Hasil penelitian tersebut menunjukkan, peningkatan nilai OLR dari 18,44 - 36,89 g/m²/hari menyebabkan peningkatan organic removal rate yaitu dari 3 - 5,3 g/l/hari.

Sedangkan penurunan konsentrasi amonia dari tangki aerasi 1 ke tangki aerasi 2 dan secondary clarifier dikarenakan adanya proses nitrifikasi. Semakin besar ammonia loading rate yang masuk maka nitrification rate semakin bertambah. Hal tersebut menunjukkan bahwa konsentrasi amonia dapat menghambat proses nitrifikasi sehingga ammonia loading rate juga semakin meningkat (Kermani et al., 2009). Serupa dengan penelitian yang dilakukan oleh (Côté et al., 2015) dengan sistem membrane aerated biofilm, ammonia loading rate dari tangki 1 ke tangki 2 dan 3 mengalami penurunan. Ammonia loading rate pada tangki 1 mencapai 12 gr $\mathrm{NH}_{3}-\mathrm{N} / \mathrm{m}^{2} /$ hari dengan nitrification rate mencapai 8 gr $\mathrm{NH}_{3}-\mathrm{N} / \mathrm{m}^{2} /$ hari. Pada tangki 2 dan 3 , ammonia loading mengalami penurunan karena sudah dilakukan pengolahan di tangki 1, sehingga menyebabkan nitrification rate juga mengalami penurunan.

\section{Aerasi $1 \square$ Aerasi $2 \square$ 2nd Clarifier}

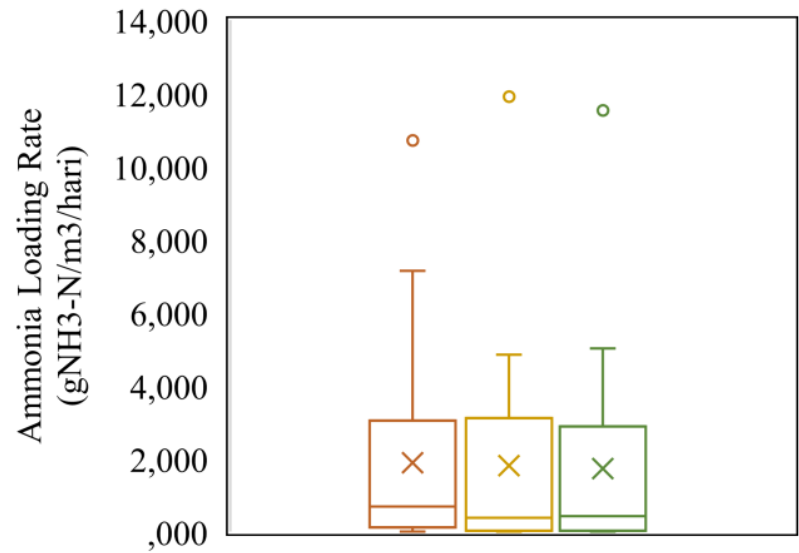

(b)

Gambar 3 Volumetric Loading Rate

(a) Organic Loading Rate, (b) Ammonia Loading Rate 


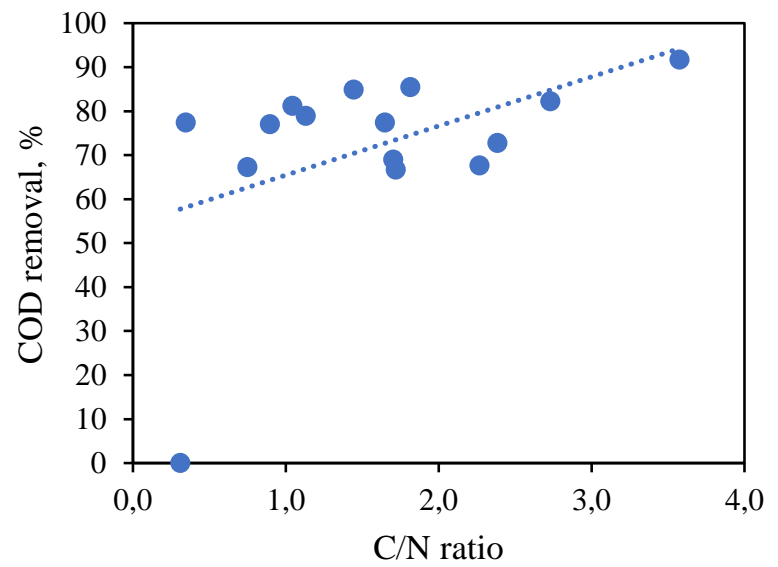

(a)

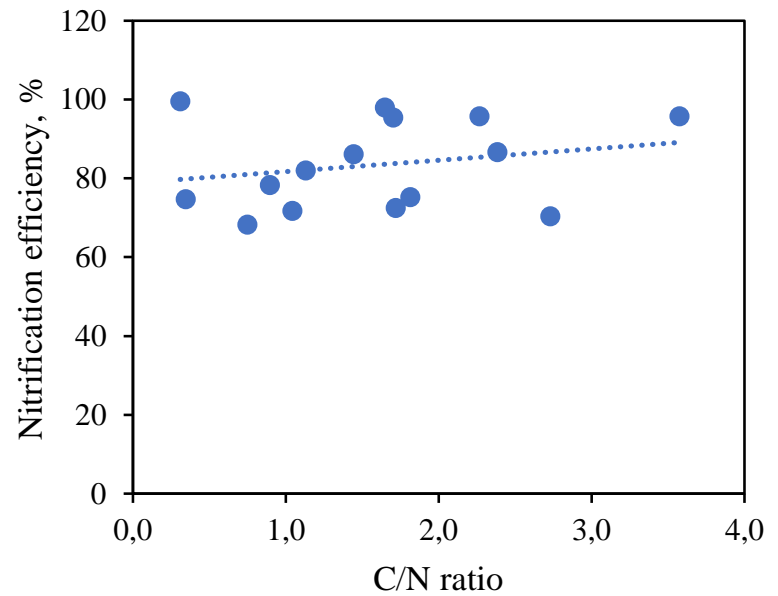

(c)

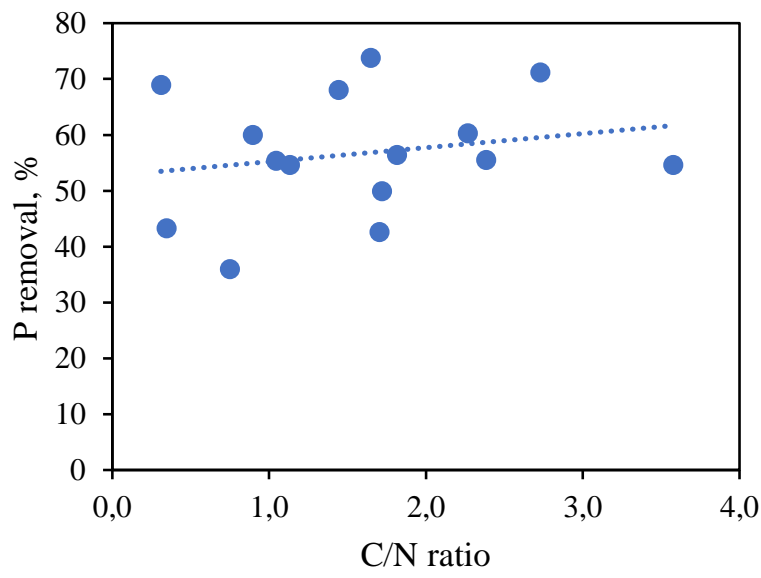

(b)

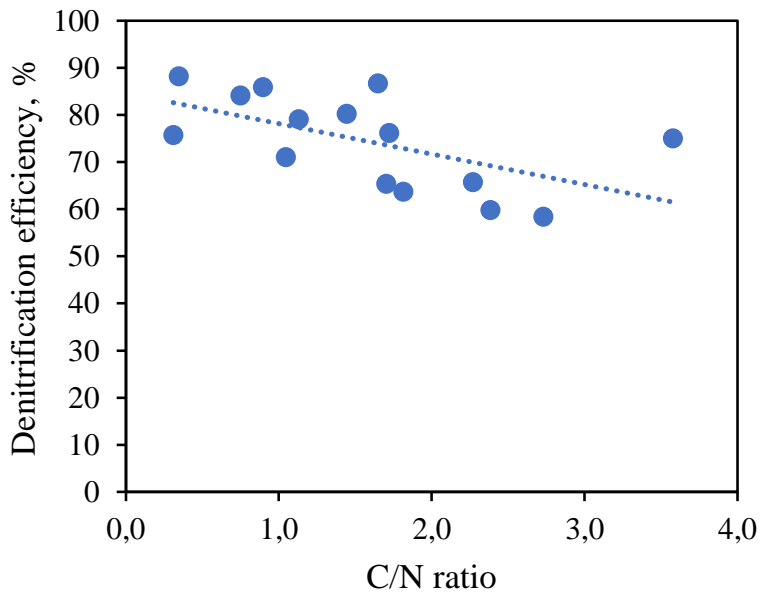

(d)

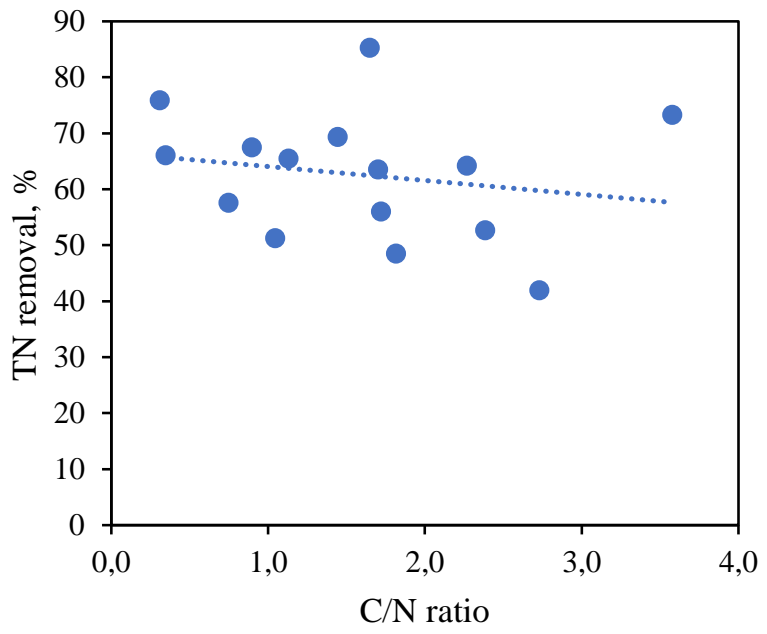

(e)

Gambar 4 Hubungan Removal dan Rasio $\mathrm{C} / \mathrm{N}$

(a) COD, (b) $\mathrm{PO}_{4}-\mathrm{P}$, (c) Nitrifikasi, (d) Denitrifikasi, (e) Total Nitrogen 
Munfaridah, A., Saraswati, S.P., Mahathir, J.S. (2022). Pengaruh Sistem Aerasi Intermittent terhadap Removal Organik dan Nitrogen pada Pengolahan Air Limbah Domestik Kamar Mandi Umum. Jurnal IImu Lingkungan, 20(1),102-114, doi: 10.14710/jil.20.1.102-114

Rasio C/N menunjukkan banyaknya material organik yang terkandung dalam air limbah (Indrayani et al., 2015). Berikut ini merupakan grafik yang menunjukkan hubungan removal parameter dan rasio $\mathrm{C} / \mathrm{N}$ yang disajikan pada Gambar 4 .

Rerata nilai rasio $\mathrm{C} / \mathrm{N}$ pada tangki aerasi $1 \mathrm{di}$ IPAL Kuningan sebesar 8:5 atau 1,6. Berdasarkan grafik hubungan rasio $\mathrm{C} / \mathrm{N}$ dan efisiensi removal diatas, semakin tinggi rasio $\mathrm{C} / \mathrm{N}$ maka efisiensi removal COD, efisiensi removal fosfat dan efisiensi nitrifikasi juga semakin meningkat. Hal serupa terjadi pada penelitian (Gou et al., 2019) dengan menggunakan teknologi bioflok. Efisiensi removal amonia nitrogen $\left(\mathrm{NH}_{3}-\mathrm{N}\right)$ pada rasio C/N 10, C/N 15, C/N 20 dan C/N 25 berturutturut sebesar 88,67\%, 94,98\%, 100\% dan 100\%. Selain itu, dengan rasio $\mathrm{C} / \mathrm{N}$ tersebut juga dapat menghasilkan efisiensi removal COD berturut-turut sebesar $91,15 \%$, 91,06\%, 95,09\% dan 95,53\%. Kondisi tersebut menunjukkan bahwa semakin besar rasio $\mathrm{C} / \mathrm{N}$ maka removal ammonia dan COD semakin besar.

Berbeda halnya hubungan antara rasio $\mathrm{C} / \mathrm{N}$ dengan removal total nitrogen dan efisiensi denitrifikasi, dimana semakin tinggi rasio $\mathrm{C} / \mathrm{N}$ maka efisiensi removal total nitrogen dan efisiensi denitrifikasi akan semakin menurun. Kondisi serupa juga terjadi pada penelitian (Iswantari et al., 2013), dimana efisiensi removal total nitrogen yang dihasilkan pada rasio $\mathrm{C} / \mathrm{N}$ 8,1, C/N 17,8, dan C/N 19,1 berturut turut sebesar $0,21 \%, 0,12 \%$ dan $0,12 \%$. Proses denitrifikasi akan mendominasi pada rasio $\mathrm{C} / \mathrm{N}$ yang rendah, sedangkan pada rasio $\mathrm{C} / \mathrm{N}$ yang tinggi akan didominasi oleh proses nitrifikasi (Rusmana, 2007).

Berdasarkan data diatas dapat dilakukan analisis statistik untuk mengetahui hubungan antara rasio $\mathrm{C} / \mathrm{N}$ dengan efisiensi removal menggunakan analisis korelasi. Analisis korelasi digunakan untuk mengetahui keeratan hubungan antara dua variabel (Nuryadi et al., 2017). Berdasarkan grafik diatas, hubungan rasio $\mathrm{C} / \mathrm{N}$ terhadap efisiensi removal COD, fosfat dan nitrifikasi memiliki hubungan linier positif dengan koefisien korelasi berturut - turut sebesar 0,47, 0,27 , dan 0,21 . Nilai koefisien korelasi antara dua variabel tersebut memiliki nilai positif $(+)$, sehingga mempunyai hubungan searah. Berdasarkan grafik dan nilai koefisien korelasi tersebut menunjukkan bahwa semakin besar nilai rasio $\mathrm{C} / \mathrm{N}$ maka efisiensi removal COD, fosfat dan nitrifikasi juga semakin besar. Sedangkan pada grafik hubungan rasio $\mathrm{C} / \mathrm{N}$ terhadap efisiensi removal total nitrogen dan efisiensi denitrifikasi, menunjukkan hubungan linier negatif dengan koefisien korelasi berturut - turut sebesar 0,58 dan $-0,2$. Nilai koefisien korelasi antara dua variabel tersebut memiliki nilai negatif (-), sehingga mempunyai hubungan berlawanan arah. Berdasarkan grafik dan nilai koefisien korelasi diatas, menunjukkan bahwa rasio $\mathrm{C} / \mathrm{N}$ berbanding terbalik dengan efisiensi denitrifikasi dan $\mathrm{TN}$ removal, dimana semakin besar rasio $\mathrm{C} / \mathrm{N}$ maka efisiensi denitrifikasi dan $\mathrm{TN}$ removal akan semakin rendah.

Faktor lain yang mempengaruhi removal parameter adalah rasio F/M. Rasio F/M menunjukkan jumlah zat organik dalam air limbah dibagi dengan massa mikroorganisme dalam tangki aerasi. Rasio F/M yang rendah menunjukkan energi mikroorganisme dalam tangki aerasi sedikit sehingga proses pengolahan limbah semakin efisien (Hammer, 1986). Berikut ini grafik hubungan rasio $\mathrm{F} / \mathrm{M}$ dan removal parameter yang disajikan pada Gambar 5.

Nilai F/M yang dianalisis di IPAL Kuningan hanya pada tangki aerasi 1 . Rerata F/M terbesar yaitu F/M COD sebesar 6,98 gCOD/gTSS/hari dengan removal sebesar 71,98\%, kemudian $\mathrm{F} / \mathrm{M}$ TN sebesar 5,28 gTN/gTSS/hari dengan rerata removal sebesar $56,67 \%$ dan rerata $\mathrm{F} / \mathrm{M}$ terkecil yaitu $\mathrm{F} / \mathrm{M}$ fosfat dengan nilai 2,39 $\mathrm{gPO}_{4}-\mathrm{P} / \mathrm{gTSS} /$ hari dan removal sebesar $62,62 \%$. Menurut (Water Resources Division, 2017) rasio F/M berkisar antara 0,2 - 0,5 untuk pengolahan lumpur aktif konvensional, untuk CSTR berkisar 0,2 - 1 dan untuk high rate berkisar 0,4-1,5. Hasil perhitungan rasio $\mathrm{F} / \mathrm{M}$ COD, TN dan fosfat terhadap TSS di IPAL Kuningan apabila dibandingkan dengan teori tersebut tergolong cukup tinggi.

Rasio F/M yang sesuai dengan nilai standar menunjukkan bahwa mikroorganisme dalam tangki akan semakin produktif dalam mendegradasi limbah sehingga pengolahan limbah akan semakin efektif. Selain itu, juga akan meningkatkan efisiensi removal kandungan TSS (Kurnia et al., 2016). Tingginya rasio F/M dapat menyebabkan kelebihan makanan yang dapat menurunkan efisiensi penyisihan bahkan terjadi bulking (Fitrahani et al., 2012). Sedangkan, rasio F/M yang lebih rendah dari batas yang diijinkan akan menyebabkan pertumbuhan mikroorganisme terjadi cepat namun nutrisi yang diberikan tidak seimbang sehingga dapat menyebabkan mikroorganisme mati dan mengurai (Ayu et al., 2002).

Berdasarkan data diatas dapat dilakukan analisis statistik untuk mengetahui hubungan antara rasio $\mathrm{F} / \mathrm{M}$ dengan efisiensi removal menggunakan analisis korelasi. Analisis korelasi digunakan untuk mengetahui keeratan hubungan antara dua variabel (Nuryadi et al., 2017). Berdasarkan grafik diatas, hubungan rasio $\mathrm{F} / \mathrm{M}$ COD dan $\mathrm{F} / \mathrm{M}$ fosfat terhadap efisiensi removal COD dan fosfat memiliki hubungan linier positif dengan koefisien korelasi berturut - turut sebesar 0,31 dan 0,32. Nilai koefisien korelasi antara dua variabel tersebut memiliki nilai positif $(+)$, sehingga mempunyai hubungan searah. Berdasarkan grafik dan nilai koefisien korelasi tersebut menunjukkan bahwa semakin besar nilai rasio $\mathrm{F} / \mathrm{M}$ 
COD dan F/M fosfat, maka efisiensi removal COD dan fosfat juga semakin besar. Sedangkan pada grafik hubungan rasio $\mathrm{F} / \mathrm{M}$ total nitrogen terhadap efisiensi removal total nitrogen, menunjukkan hubungan linier negatif dengan koefisien korelasi sebesar $-0,33$. Nilai koefisien korelasi antara dua variabel tersebut

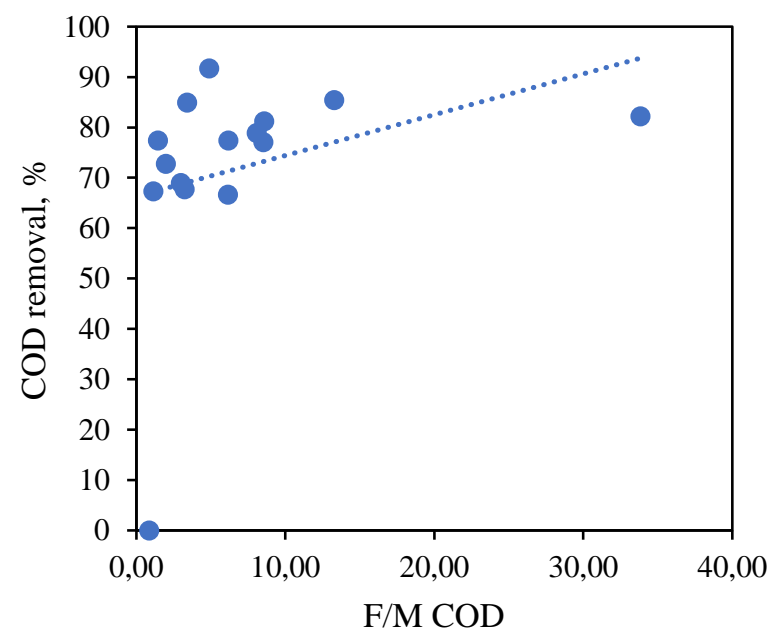

memiliki nilai negatif (-), sehingga mempunyai hubungan berlawanan arah. Berdasarkan grafik dan nilai koefisien korelasi diatas, menunjukkan bahwa rasio $\mathrm{F} / \mathrm{M}$ total nitrogen berbanding terbalik dengan efisiensi removal TN, dimana semakin besar rasio $\mathrm{F} / \mathrm{M}$ maka efisiensi removal TN akan semakin rendah

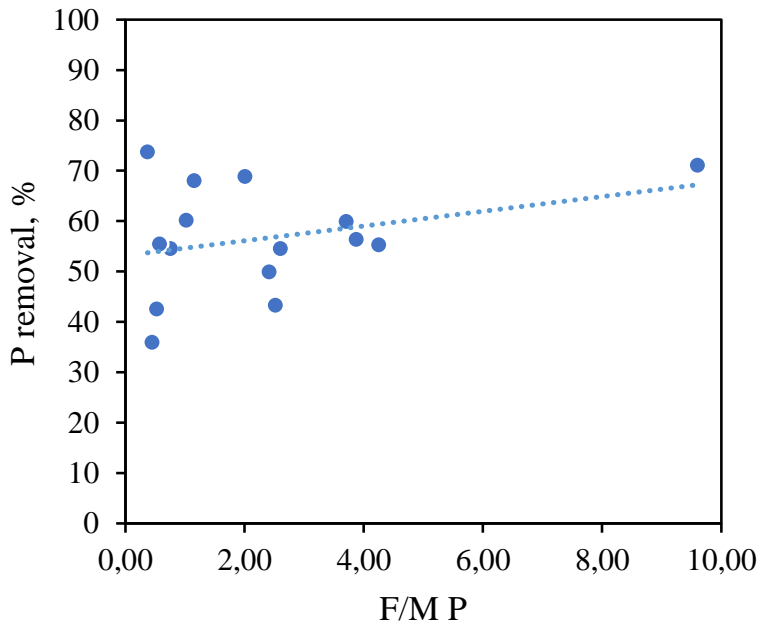

(a)

(b)

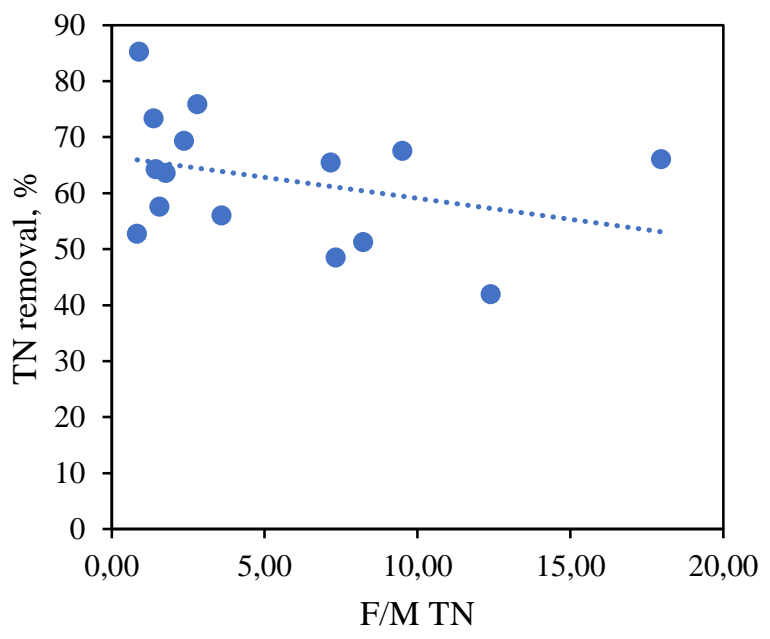

(c)

Gambar 5 Hubungan Removal dan Rasio F/M

Tabel 5 Konsumsi Energi dalam Removal Parameter

\begin{tabular}{ccccc}
\hline & $\mathrm{COD}$ & $\mathrm{PO}_{4}-\mathrm{P}$ & $\mathrm{NH}_{3}-\mathrm{N}$ & $\mathrm{TN}$ \\
\hline Removal rerata, mg/l & 61,53 & 14,42 & 48,79 & 32,43 \\
Removal rerata, g & 333,21 & 78,10 & 264,23 & 175,62 \\
kWh/g-removed & 0,8 & 3,42 & 1,01 & 1,52 \\
g-removed/kWh & 1,25 & 0,29 & 0,99 & 0,66 \\
\hline
\end{tabular}




\subsection{Konsumsi Energi}

Energi yang dikonsumsi selama proses pengolahan diamati dalam bentuk energi listrik yang tersambung pada pompa MBG dan blower. MBG digunakan untuk proses aerasi intermittent sedangkan blower digunakan untuk aerasi kontinyu. Setiap bentuk konsumsi energi dihitung dalam $\mathrm{kWh} / \mathrm{m}^{3}$ air limbah yang diolah. Pemantauan lapangan telah dilakukan selama 66 hari yang tersebar selama 3 bulan selama bulan Oktober - Desember 2020. Konsumsi listrik per meter kubik air limbah total menghasilkan 49,27 $\mathrm{kWh} / \mathrm{m}^{3}$ atau $4,04 \mathrm{kWh} / \mathrm{hari}$. Nilai $\mathrm{kWh} / \mathrm{m}^{3}$ tidak dipengaruhi oleh debit resirkulasi hanya dipengaruhi oleh debit aktual yang masuk. Tabel diatas menunjukkan bahwa sebagian besar konsumsi energi di IPAL Kuningan digunakan untuk pompa MBG yaitu sebesar $244,32 \mathrm{kWh} / \mathrm{m}^{3}$, sedangkan konsumsi energi untuk blower hanya sebesar $22,50 \mathrm{kWh} / \mathrm{m}^{3}$. Hal tersebut menunjukkan bahwa proses aerasi intermittent lebih banyak membutuhkan energi dibandingkan aerasi kontinyu, dikarenakan pompa MBG akan menyala selama 15 menit kemudian kembali mati selama 15 menit sehingga listrik yang digunakan lebih banyak dibandingkan dengan pompa blower yang terus menyala selama 24 jam. Besar konsumsi listrik yang dibutuhkan pompa untuk proses aerasi berdasarkan perhitungan desain IPAL Kuningan yaitu sebesar 3,85 $\mathrm{kWh} / \mathrm{m}^{3}$ untuk kapasitas debit 1.050 liter/hari. Hal ini menunjukkan bahwa semakin besar debit yang masuk ke IPAL maka konsumsi listrik yang dibutuhkan semakin kecil.

Berdasarkan penelitian yang dilakukan (Bodík \& Kubaská, 2013) menunjukkan bahwa sistem aerasi dengan konsentrasi oksigen dibawah 1,5 - $2 \mathrm{mg} / \mathrm{l}$ akan membutuhkan konsumsi energi lebih banyak, dimana pada pengolahan dengan sistem aerasi intermittent terjadi proses denitrifikasi dengan konsentrasi oksigen rendah $<2 \mathrm{mg} / \mathrm{l}$. Konsumsi energi dengan sistem aerasi menghabiskan sekitar $60-65 \%$ dari keseluruhan biaya pengoperasian air limbah. Selain itu konsumsi energi berkorelasi dengan removal COD, fosfat dan total nitrogen. Berikut ini merupakan hasil konsumsi energi dalam removal kontaminan yang disajikan pada Tabel 5 .

Berdasarkan tabel diatas menunjukkan bahwa konsumsi energi untuk menyisihkan fosfat memiliki nilai terbesar dibandingkan penyisihan parameter lainnya. Konsumsi energi terbesar untuk peyisihan fosfat yaitu 3,42 $\mathrm{kWh} / \mathrm{gPO}_{4}-\mathrm{P}$, kemudian penyisihan ammonia sebesar $1,01 \mathrm{kWh} / \mathrm{gNH}_{3}-\mathrm{N}$, dan yang terkecil penyisihan COD sebesar 0,8 kWh/gCOD. Hal tersebut menunjukkan bahwa konsumsi energi meningkat dengan meningkatnya konsentrasi kontaminan yang berpengaruh yaitu COD, fosfat, ammonia dan total nitrogen. Apabila dibandingkan dengan perhitungan desain IPAL Kuningan, konsumsi energi yang dibutuhkan untuk menyisihkan COD sebesar 464 gram/hari adalah 0,58 kWh/gCOD.

Efisiensi energi memiliki kinerja yang baik ketika removal kontaminan tinggi dan sebaliknya efisiensi energi memiliki kinerja yang buruk ketika removal kontaminan sedikit (Li et al., 2019). Menurut penelitian (Lang et al., 2020) dengan sistem electrochemical oxidation, konsumsi energi yang dihasilkan untuk menyisihkan ammonia sebesar $0,056 \mathrm{kWh} / \mathrm{g} \mathrm{NH}-\mathrm{N}$ dan untuk menyisihkan COD sebesar $0,026 \mathrm{kWh} / \mathrm{gCOD}$ dengan total konsumsi energi $0,27 \mathrm{kWh} / \mathrm{m}^{3}$. Kondisi ini sama apabila dibandingkan dengan penelitian di IPAL Kuningan, dimana konsumsi energi untuk penyisihan $\mathrm{NH}_{3}-\mathrm{N}$ lebih besar dibandingkan untuk penyisihan COD.

Biaya yang dibutuhkan mengolah $1 \mathrm{~m}^{3}$ air limbah di IPAL Kuningan sebesar Rp 71.190,00 atau biaya per bulan sebesar Rp 175.249,00. Apabila dibandingkan dengan perhitungan desain IPAL Kuningan, biaya yang dibutuhkan untuk mengolah $1 \mathrm{~m}^{3}$ air limbah hanya sebesar $\mathrm{Rp}$ 4.621,00. Biaya yang dikeluarkan untuk pengolahan dipengaruhi oleh debit yang masuk. Semakin besar debit air limbah yang diolah maka konsumsi energi yang dibutuhkan akan semakin kecil, sehingga biaya yang dikeluarkan juga semakin kecil ( $\mathrm{Li}$ et al., 2019).

\section{Kesimpulan}

Berdasarkan hasil penelitian yang dilakukan di IPAL Kuningan rerata debit aktual sebesar 82,06 liter/hari dengan hasil uji parameter COD telah memenuhi baku mutu, sedangkan parameter fosfat dan amonia masih belum memenuhi baku mutu PerMenLHK No.68 Tahun 2016 dan PerDa DIY No. 7 Tahun 2016 dikarenakan terjadi peningkatan konsentrasi fosfat dan amonia dari inlet di akhir penelitian. Rerata hasil performa removal COD sebesar $74,62 \pm 19,38 \%$, removal fosfat sebesar $56,88 \pm 10,52 \%$, removal total nitrogen sebesar $62,43 \pm 12,45 \%$, efisiensi nitrifikasi sebesar $84,41 \pm 12,38 \%$ dan efisiensi denitrifikasi sebesar $72,42 \pm 12,15 \%$. Performa removal COD, fosfat, dan nitrifikasi menunjukkan peningkatan dari tangki aerasi 1 ke tangki aerasi 2. Sedangkan performa removal total nitrogen dan nitrifikasi menunjukkan terjadi penurunan removal dari tangki aerasi 1 ke tangki aerasi 2.

Total konsumsi energi yang dibutuhkan untuk pengolahan air limbah di IPAL Kuningan dengan debit rerata $82,06 \mathrm{l} /$ hari sebesar $49,27 \mathrm{kWh} / \mathrm{m}^{3}$ dan biaya sebesar Rp 71.190,00/ $\mathrm{m}^{3}$. Konsumsi energi terbesar IPAL digunakan untuk peyisihan fosfat yaitu 0,29 $\mathrm{kWh} / \mathrm{gPO}_{4}-\mathrm{P}$, kemudian penyisihan ammonia sebesar 
$0,99 \mathrm{kWh} / \mathrm{gNH}_{3}-\mathrm{N}$, dan yang terkecil penyisihan COD sebesar 1,25 kWh/gCOD.

\section{DAFTAR PUSTAKA}

Ajit, K. (2016). A Review on Grey Water Treatment and Reuse. International Research Journal of Engineering and Technology, 2395-56. https://www.irjet.net/archives/V3/i5/IRJETV3I5551.pdf

Ávila, C., Pelissari, C., Sezerino, P. H., Sgroi, M., Roccaro, P., \& García, J. (2017). Enhancement of total nitrogen removal through effluent recirculation and fate of PPCPs in a hybrid constructed wetland system treating urban wastewater. Science of the Total Environment, 584-585, 414-425. https://doi.org/10.1016/j.scitotenv.2017.01.024

Ayu, C., Anggraeni, D., Kurniasari, S., \& Ismail, T. (2002). Penggunaan Membran Bioreaktor ( $M B R$ ) Pada Activated Sludge Dalam Pengolahan Limbah Cair Industri. 2309105004.

Bodík, I., \& Kubaská, M. (2013). Energy and sustainability of operation of a wastewater treatment plant. Environment Protection Engineering, 39(2), 15-24. https://doi.org/10.5277/EPE130202

Côté, P., Peeters, J., Adams, N., Hong, Y., Long, Z., \& Ireland, J. (2015). A new membrane-aerated biofilm reactor for low energy wastewater treatment: Pilot results. 88th Annual Water Environment Federation Technical Exhibition and Conference, WEFTEC 2015, 6(January), 4226-4239.

https://doi.org/10.2175/193864715819540883

Fitrahani, L. Z., Indrasti, N. S., \& Suprihatin. (2012). Karakterisasi Kondisi Operasi dan Optimasi Proses Pengolahan Air Limbah Industri Pangan. E-Jurnal Agroindustri Indonesia, 1(2), 110-117. http://journal.ipb.ac.id/index.php/e-jaii/index

Gou, J., Hong, C. U., Deng, M., Chen, J., Hou, J., Li, D., \& He, X. (2019). Effect of carbon to nitrogen ratio on water quality and community structure evolution in suspended growth bioreactors through biofloc technology. Water (Switzerland), 11(8). https://doi.org/10.3390/w11081640

Hammer. (1986). Water and Wastewater Technology. John Wiley and Sons.

Hanafi, F. (2019). Evaluasi Kinerja Instalasi Pengolahan Air Limbah (Ipal) Industri Penyamakan Kulit Di Pt.X. https://help.uii.ac.id/bitstream/handle/123456789/ 16311/08 naskah publikasi.pdf?sequence $=17$ \&isAllowed $=y$

Indrayani, E., Nitimulyo, K. H., Hadisusanto, S., \& Rustadi, R. (2015). Analisis kandungan nitrogen, fosfor dan karbon organik di Danau Sentani - Papua. Jurnal Manusia Dan Lingkungan, 22(2), 217-225.

Iswantari, A., Wardiatno, Y., Pratiwi, N., \& Rusmana, I. (2013). Fluks Bentik dan Potensi Aktivitas Bakteri Terkait Siklus Nitrogen di Sedimen Perairan Mangrove Pulau Dua, Banten (Benthic Fluxes and Potency of Bacterial Activity Related to Nitrogen Cycle in Pulau
Dua Mangrove Sediments, Banten). 10(1), 109-117.

Kementerian Lingkungan Hidup dan Kehutanan. (2019). Indeks Kualitas Lingkungan Hidup 2019 (Vol. 53, Issue 9). Kementerian Lingkungan Hidup dan Kehutanan. http://www.elsevier.com/locate/scp

Kermani, M., Bina, B., Movahedian, H., Amin, M. M., \& Nikaeen, M. (2009). Biological phosphorus and nitrogen removal from wastewater using moving bed biofilm process. Iranian Journal of Biotechnology, 7(1), 19-27.

Kurnia, A., Sandi, S., Dermawan, D., \& Afiuddin, A. E. (2016). Pengaruh F / M Rasio dan Waktu Detensi Aerasi terhadap Efisiensi Removal TSS pada Pengolahan Limbah Cair Domestik Metode Conventional Activated Sludge. 2623, 125-128.

Lang, Z., Zhou, M., Zhang, Q., Yin, X., \& Li, Y. (2020). Comprehensive treatment of marine aquaculture wastewater by a cost-effective flow-through electrooxidation process. Science of the Total Environment, 722,

137812 https://doi.org/10.1016/j.scitotenv.2020.137812

Li, Z., Zou, Z., \& Wang, L. (2019). Analysis and Forecasting of the Energy Consumption in Wastewater Treatment Plant. Mathematical Problems in Engineering, 2019. https://doi.org/10.1155/2019/8690898

Metcalf, \& Eddy. (2003). Wastewater Engineering Treatment and Reuse, 4th Edition (4th ed.). McGraw-Hill.

Najafpour, G. D., Zinatizadeh, A. A. L., \& Lee, L. K. (2006). Performance of a three-stage aerobic RBC reactor in food canning wastewater treatment. Biochemical Engineering Journal, 30(3), 297-302. https://doi.org/10.1016/j.bej.2006.05.013

Nuryadi, Astuti, T. D., Utami, E. S., \& Budaintara, M. (2017). Dasar-Dasar Statistika Penelitian. http://lppm.mercubuana-yogya.ac.id/wpcontent/uploads/2017/05/Buku-Ajar_Dasar-DasarStatistik-Penelitian.pdf

Rusmana, I. (2007). Effects of Temperature on Denitrifying Growth and Nitrate Reduction End Products of Comamonas testosteroni Isolated from Estuarine Sediment. MIcrobiology Indonesia, 1(1), 43-47. https://doi.org/10.5454/mi.1.1.10

Said, N. I., \& Utomo, K. (2018). Pengolahan Air Limbah Domestik Dengan Proses Lumpur Aktif Yang Diisi Dengan Media Bioball. Jurnal Air Indonesia, 3(2), 160174. https://doi.org/10.29122/jai.v3i2.2337

Tendean, C., Tilaar, S., \& Karongkong, H. H. (2014). Pengelolaan Air Limbah Domestik di Permukiman Kumuh di Kelurahan Calaca dan Istiqlal Kecamatan Wenang. Sabua, 6(3), 293-306.

Torkaman, M., Borghei, S. M., Tahmasebian, S., \& Andalibi, M. R. (2015). Nitrogen removal from high organic loading wastewater in modified Ludzack-Ettinger configuration MBBR system. Water Science and Technology, 72(8), 1274-1282. https://doi.org/10.2166/wst.2015.343

von Sperling, M., Verbyla, M. E., \& Oliveira, S. M. A. C. (2020). Assessment of Treatment Plant Performance and Water Quality Data: A Guide for Students, Researchers and Practitioners. In Assessment of Treatment Plant Performance and Water Quality Data: A Guide for 
Munfaridah, A., Saraswati, S.P., Mahathir, J.S. (2022). Pengaruh Sistem Aerasi Intermittent terhadap Removal Organik dan Nitrogen pada Pengolahan Air Limbah Domestik Kamar Mandi Umum. Jurnal IImu Lingkungan, 20(1),102-114, doi: 10.14710/jil.20.1.102-114

Students, Researchers and Practitioners. https://doi.org/10.2166/9781780409320

Water Resources Division. (2017). Activated Sludge Process
Control: Training Manual for Wastewater Treatment Plant Operators. 